\title{
PRAWOTWÓRCZE KOMPETENCJE WŁADZY WYKONAWCZEJ W ZAKRESIE PRAWA POWSZECHNIE OBOWIAZZUJĄCEGO W KONSTYTUCJI RP Z 1997 R. - STAN OBECNY I POSTULATY DE LEGE FERENDA
}

W zaproszeniu do udziału w konferencji naukowej, której pokłosie stanowi niniejszy zbiór publikacji, jej Organizatorzy stwierdzili: „Tezą konferencji jest tendencja ewoluowania systemów rządów poprzez modyfikację polegającą na wzmacnianiu egzekutywy". Biorąc pod uwagę nasilającą się w Europie po II wojnie światowej racjonalizację systemu parlamentarnego, owa ogólna teza wydaje się trafna. Zjawisko to narodziło się w reakcji na niestabilność gabinetów, charakteryzującą III Republikę Francuską, gdy poważnemu zachwianiu uległa równowaga między legislatywą a egzekutywą (parlament wyraźnie zdominował władzę wykonawczą), a przejawiało się to zwłaszcza łatwością w egzekwowaniu odpowiedzialności politycznej rządu ${ }^{1}$. Początkowo proces racjonalizacji polegał głównie na jurydyzacji mechanizmów odpowiedzialności parlamentarnej, bo brak ich konstytucyjnego, formalnego sprecyzowania był podstawowym źródłem dysfunkcjonalności systemu parlamentarnego, umożliwiając dorozumiane wyrażanie wotum nieufności i powodując częste kryzysy rządowe - dlatego też wprowadzano takie elementy proceduralne, jak np. wyższe quorum podczas głosowania nad wnioskiem o wotum nieufności, konieczność złożenia określonej liczby podpisów pod wnioskiem, wymóg osiągnięcia większości bezwzględnej czy obowiązek odczekania z głosowaniem². Później racjonalizacja parlamentaryzmu objęła kolejne aspekty tego systemu rządów, zmierzając w kierunku wzmocnienia pozycji ustrojowej bądź prezydenta, bądź rządu³. W obu wariantach podkreślenie znaczenia ustrojowego władzy wykonawczej kosztem parlamentu miało służyć usprawnieniu systemu ${ }^{4}$. Jak spostrzegł Jarosław Szymanek, choć celem racjonalizacji było przywrócenie zaburzonej równowagi między władzą ustawodaw-

Zob. J. Szymanek, Racjonalizacja parlamentarnego systemu rządów, „Przegląd Sejmowy” 2007, nr 1, s. 39-41. Ibidem, s. 44

A. Łabno wyróżnia „mocną" (proprezydencką, jak to ma miejsce w systemie półprezydenckim) i „słabszą” (prorządową - w ramach systemu parlamentarnego) wersję parlamentaryzmu zracjonalizowanego (zob. A. Łabno, Parlamentaryzm zracjonalizowany. Przyczynek do dyskusji, „Przegląd Prawa i Administracji” 2005, t. LXV, s. 10). 
czą a wykonawczą, to w efekcie „równowaga ta nie została osiągnięta, a skutkiem zabiegów racjonalizujących okazało się jedynie przesunięcie punktu ciężkości z parlamentu na jeden z segmentów władzy wykonawczej"s.

Racjonalizacja parlamentaryzmu nie wszędzie jednak osiągnęła tę samą fazę zaawansowania i nie zawsze jest konsekwentna. Przykładowo Konstytucja RP z dnia 2 kwietnia $1997 \mathrm{r}^{6}{ }^{6}$ zasadniczo ustanawia zracjonalizowany w kierunku prorządowym $^{7}$ system parlamentarny ${ }^{8}$, ale dokonuje zarazem istotnych koncesji na rzecz Prezydenta $\mathrm{RP}^{9}$, co przejawia się m.in. jego pochodzeniem z wyborów powszechnych i dysponowaniem prerogatywą w postaci ,przełamywanego" większością 3/5 głosów weta ustawodawczego ${ }^{10}$. Korzystną dla gabinetu racjonalizacją w największym stopniu objęto sferę jego odpowiedzialności parlamentarnej, poprzez wprowadzenie konstruktywnego wotum nieufności jako jedynego instrumentu egzekwowania odpowiedzialności politycznej Rady Ministrów przed Sejmem. Z drugiej jednak strony, istnieją w Polsce rozwiązania niemające wiele wspólnego ze wzmacnianiem pozycji ustrojowej rządu, choć to właśnie rząd prowadzi politykę zagraniczną i wewnętrzną państwa (art. 146 ust. 1 Konstytucji).

Powyższa konstatacja znajduje szczególne potwierdzenie przy okazji analizy kompetencji prawotwórczych egzekutywy w sferze prawa powszechnie obowiązującego. Z punktu widzenia klarowności systemu rządów słusznie uczyniono, ograniczając w tym zakresie rolę Prezydenta RP. Sprowadza się ona do dysponowania kompetencją do wydawania - ale tylko w czasie stanu wojennego i po spełnieniu wymienionych w Konstytucji warunków, w tym wystąpienia $\mathrm{z}$ wnioskiem przez rząd - rozporządzeń z mocą ustawy, a ponadto rozporządzeń wykonawczych. Z kolei Rada Ministrów, premier, ministrowie „działowi” i przewodniczący komitetów określonych w ustawach dysponują jedynie tym drugim uprawnieniem, co wydaje się niewystarczające, skoro zarazem powierzono rządowi prowadzenie polityki państwa. Należy podzielić opinię Sławomira Patyry, że przypisaniu Radzie Ministrów funkcji organu prowadzącego politykę państwa towarzyszyć powinno wy-

Ibidem, s. 63

Dz.U. z 1997 r. Nr 78, poz. 483 z późn. zm. Dalej: Konstytucja lub Konstytucja RP.

Choć w ustroju RP odnaleźć można podobieństwa do systemu półprezydenckiego, to wciąż stanowi on przykład zracjonalizowanego parlamentaryzmu, zob. T. Borkowski, System rządów w nowej Konstytucji, „Państwo i Prawo" 1997, z. 11-12, s. 81-85 (autor ten traktuje system półprezydencki jako odrębny system rządów, a nie system parlamentarny w wariancie „mocnej” racjonalizacji).

Por. np. W. Brodziński, System parlamentarno-gabinetowy - wykorzystanie modelu rządów parlamentarno-gabinetowych w konstytucji Rzeczypospolitej Polskiej, (w:) M. Domagała (red.), Konstytucyjne systemy rządów. Możliwości adaptacji do warunków polskich, Warszawa 1997, s. 55; M. Kruk, System rządów w Konstytucji Rzeczypospolitej Polskiej z 2 kwietnia 1997 roku, (w:) W. Skrzydło, R. Mojak (red.), Ustrój polityczny Rzeczypospolitej Polskiej w nowej Konstytucji z 2 kwietnia 1997 roku, Lublin 1998, s. 50.

W tym kontekście krytyce podlega opowiedzenie się przez ustrojodawcę za „mocnym prezydentem i mocnym premierem" jednocześnie (tak B. Banaszak, Egzekutywa w Polsce - stan obecny i uwagi de lege fundamentali ferenda, „Przegląd Sejmowy” 2006, nr 3, s. 9).

Bywa to stanowczo krytykowane, zob. np. R. Balicki, Relacje między organami władzy wykonawczej - na drodze do systemu kanclerskiego?, (w:) B. Banaszak, M. Jabłoński (red.), Konieczne i pożądane zmiany w Konstytucji RP z 2 kwietnia 1997 roku, Wrocław 2010, s. 344-346. 
posażenie jej w ,podstawowe instrumentarium” służące realizacji tej funkcji ${ }^{11}$. Jak spostrzega zaś Maria Kruk, podział władzy przeprowadzony tak, że parlamentowi przypada w udziale ustawodawstwo, a rządowi władza wykonawcza, może zarówno stać na przeszkodzie efektywności rządu (gdyż to od parlamentu zależy uchwalanie ustaw), jak i ją wspomagać (skoro to gabinet wykonuje ustawy) ${ }^{12}$. Wydaje się jednak, że uprawnienia Rady Ministrów ukształtowano w omawianym kontekście zbyt wąsko. Z jednej strony bowiem, co zauważa również M. Kruk, „w zakresie owego dylematu: demokracja-efektywność i efektywność-równowaga, w procesie ustawodawczym Konstytucja nie daje rządowi żadnej instytucjonalnej gwarancji skuteczności wbrew parlamentowi, czyli kosztem uprawnień parlamentu"13. Z drugiej zaś ustawa zasadnicza nie zna jakichkolwiek instrumentów prawnych, po które mógłby sięgnąc gabinet w razie sprzeciwu parlamentu wobec rządowych projektów ustaw. Tymczasem to za sprawą tych instrumentów możliwe byłoby wprowadzanie do systemu prawnego aktów normatywnych rangi ustawy, a co za tym idzie - realizacja programu politycznego gabinetu na tej właśnie, alternatywnej dla uchwalania ustaw, drodze. W rezultacie umożliwione zostałoby sprawne prowadzenie polityki państwa przez każdą Radę Ministrów - również skonfliktowaną z większością parlamentarną.

Zakres uprawnień prawotwórczych egzekutywy na gruncie obecnej Konstytucji RP zasługuje na aprobatę jedynie połowicznie. Jak już wspomniano, słusznie ograniczono w tej mierze znaczenie głowy państwa. Wydawane przez Prezydenta w czasie stanu wojennego rozporządzenia z mocą ustawy (art. 234 Konstytucji) mają wyjątkowy charakter. Zarazem z uwagi na konieczność współdziałania z Radą Ministrów, i to inicjowanego - poprzez złożenie odpowiedniego wniosku - właśnie przez ten ostatni organ, ryzyko nadmiernej, sprzecznej z planami rządu, aktywności głowy państwa zostało tutaj wyeliminowane ${ }^{14}$. Wolno pokusić się o ocenę, że ta akurat kompetencja odpowiednio współgra z funkcją Prezydenta jako gwaranta ciągłości władzy państwowej, nie kolidując też z charakterem Rady Ministrów jako organu prowadzącego politykę państwa. Natomiast trafnie zauważa się mankamenty szczegółowej regulacji zawartej w art. 234 ust. 1, a zwłaszcza jej braki, powodujące zbyt

11 Zob. S. Patyra, Mechanizmy racjonalizacji procesu ustawodawczego w Polsce w zakresie rządowych projektów ustaw, Toruń 2012, s. 311. Autor ten wyraża swój pogląd w związku ze zbyt słabą, jego zdaniem, pozycją ustrojową rządu w procesie ustawodawczym. Jednak w jego opinii zasadne byłoby rozważenie nie tylko poszerzenia uprawnień Rady Ministrów w tym procesie, ale i przywrócenie rządowych rozporządzeń z mocą ustawy (zob. ibidem, s. 279).

12 M. Kruk, Idea stabilności i efektywności rządów w Konstytucji RP z 1997 r., (w:) W. Czapliński (red.), Prawo w XXI wieku. Księga pamiątkowa 50-lecia Instytutu Nauk Prawnych Polskiej Akademii Nauk, Warszawa 2006, s. 417. Z uwagi na konieczność czynienia zadość wymogom demokracji M. Kruk nie krytykuje jednak tak ukształtowanego podziału władzy.

13 Ibidem, s. 416.

14 Wykładnia literalna art. 234 ust. 1 Konstytucji zdaje się także wykluczać odmowę wydania takiego rozporządzenia przez Prezydenta w razie pojawienia się wniosku rządowego („Prezydent Rzeczypospolitej na wniosek Rady Ministrów wydaje rozporządzenia z mocą ustawy” - a nie „może wydawać”; pytanie jednak brzmi, na ile do jednoznacznego brzmienia przepisu gotowi byliby się dostosować piastuni urzędu prezydenckiego, gdyby przedmiotowa regulacja znalazła praktyczne zastosowanie). 
wiele niewiadomych ${ }^{15}$. De lege ferenda należy postulować doprecyzowanie owych unormowań, tak aby zminimalizować wątpliwości interpretacyjne. Chodzi wszak o instrument prawny, mający znajdować zastosowanie w dramatycznym okresie stanu wojennego, gdy sprawujący w normalnych warunkach władzę ustawodawczą parlament nie może funkcjonować. Na poziomie ogólnym natomiast konstrukcja $\mathrm{z}$ art. 234 Konstytucji nie wymaga zmian.

Uwagę o braku potrzeb zmian wolno też odnieść do rozporządzeń „zwykłych”. Nie wzbudza zastrzeżeń przyznanie prawa do ich wydawania także Prezydentowi RP, choć to nie on, a Rada Ministrów, jest wiodącym organem władzy wykonawczej. Po pierwsze, w pewnych sferach zasadne jest upoważnienie do wydawania rozporządzeń głowy państwa, a nie gabinetu lub któregoś z jego członków. Za przykład mogą uchodzić rozporządzenia dotyczące szczegółów ustroju sądów administracyjnych ${ }^{16}$. Sądy te sprawują kontrolę nad działalnością organów administracji publicznej, w tym organów administracji rządowej. Nie byłoby wskazane, aby to rząd lub minister wydawał rozporządzenia regulujące ustrojowe zagadnienia sądownictwa administracyjnego. Po drugie, rozporządzenia z art. 92 Konstytucji mają charakter wykonawczy względem ustaw. Za ich pomocą nie jest możliwe prowadzenie w istotniejszym wymiarze konkurencyjnej w stosunku do gabinetu polityki państwa przez Prezydenta, a jedynie wykonywanie uchwalonych ustaw, i to w ramach zakreślonych przez zawarte w upoważnieniu ustawowym wytyczne treściowe (art. 92 ust. 1 zd. 2 Konstytucji).

W kontekście wytycznych rodzi się pytanie o to, czy ich wprowadzenie przez Konstytucję z 1997 r. jako obowiązkowego elementu konstrukcyjnego upoważnienia ustawowego do wydania rozporządzenia ${ }^{17}$ nadmiernie nie ogranicza uprawnienia prawotwórczego Rady Ministrów i jej członków. Niewątpliwie swoboda normowania została przez ustanowienie powyższego wymogu zredukowana. Jednak takie rozwiązanie daje się przekonująco uzasadnić ściśle wykonawczym charakterem rozporządzenia. Rozporządzenia nie stanowią aktów samoistnych; mają jedynie regulować w sposób szczegółowy materie, które w ustawie zostały unormowane ogólnie. Jak podkreśla Sławomira Wronkowska, ,akt wykonawczy ma swój samodzielny przedmiot regulacji, ale jest on funkcjonalnie związany z ustawą $\mathrm{w}$ tym sensie, że bez tej regulacji ustawa nie mogłaby być stosowana lub realizowana zgodnie z zamysłem ustawodawcy" ${ }^{18}$. Z przywołanej charakterystyki rozporządzeń wynika, że ich wydawanie nie wiąże się z realizacją funkcji Rady Ministrów prowadzenia po-

Zob. K. Prokop, O dopuszczalności oraz zakresie przedmiotowym rozporządzeń z mocą ustawy w czasie stanu wojennego, „Przegląd Sejmowy” 2002, nr 3, s. 47 i n.

Zob. np. rozporządzenie Prezydenta RP z dnia 5 sierpnia 2015 r. - Regulamin wewnętrznego urzędowania wojewódzkich sądów administracyjnych (Dz.U. z 2015 r. poz. 1177).

W literaturze podkreślano doniosłość wprowadzenia wymogu wytycznych, zob. np. K. Działocha, uwaga nr 15 do art. 92, (w:) L. Garlicki (red.), Konstytucja Rzeczypospolitej Polskiej. Komentarz, t. II, Warszawa 2001, s. 24-25.

S. Wronkowska, Model rozporządzenia jako aktu wykonawczego do ustaw w świetle Konstytucji i praktyki, (w:) A. Szmyt (red.), Konstytucyjny system źródeł prawa w praktyce, Warszawa 2005, s. 78. 
lityki państwa. Nie są to akty o zasadniczym, a o subsydiarnym znaczeniu w sferze prawotwórstwa. Koncepcja rozporządzenia zakłada podporządkowanie organu władzy wykonawczej parlamentowi, a wymóg zawarcia w upoważnieniu ustawowym wytycznych treściowych dobrze z tą koncepcją współgra, chroniąc zarazem obywateli i inne podmioty prywatne, do których może być adresowane rozporządzenie, przed niekontrolowaną aktywnością prawotwórczą organu niebędącego bezpośrednim przedstawicielem suwerena. Z powyższych względów opowiadałbym się za utrzymaniem obecnej konstrukcji rozporządzeń, zdając sobie przy tym sprawę, że w praktyce często prawidłowość sformułowania wytycznych treściowych i zmieszczenia się w ich ramach przez rozporządzeniodawcę budzi wątpliwości ${ }^{19}$. Wydaje się jednak, że tego typu wątpliwości nie sposób wyeliminować w drodze zmian w Konstytucji, a rozstrzygać je powinien nadal Trybunał Konstytucyjny.

W porównaniu z Małą konstytucją z $1992 \mathrm{r}^{20}{ }^{20} \mathrm{~W}$ ramach kompetencji prawotwórczych rządu nastąpił jednak regres, uzasadniający wyrażoną powyżej ambiwalentną ocenę aktualnych unormowań. Gabinet utracił bowiem prawo wydawania rozporządzeń z mocą ustawy. Brak tego (lub porównywalnego) uprawnienia w obecnej Konstytucji oceniam jako mankament. Stąd też de lege ferenda postulowałbym restytucję w ramach systemu źródeł prawa rządowego ustawodawstwa delegowanego służącego prowadzeniu polityki państwa (a nie tylko przewidzianego na użytek stanu nadzwyczajnego). Ponieważ zaś MK bezpośrednio poprzedziła aktualnie obowiązującą ustawę zasadniczą, warto jej postanowienia dotyczące omawianej instytucji prawnej uczynić punktem odniesienia dla rozważań nad pożądanym kształtem rządowych dekretów ${ }^{21}$, gdyby miały one powrócić do systemu źródeł prawa ${ }^{22}$. Wcześniej jednak należy zastanowić się nad przyczynami dostrzegalnej obecnie niechęci do rozporządzeń z mocą ustawy wydawanych w czasie normalnego funkcjonowania państwa.

19 Szerzej zob. M. Żabicka-Kłopotek, „Wytyczne” jako element upoważnienia do wydania rozporządzenia (na tle artykułu 92 Konstytucji RP), „Przegląd Sejmowy” 2006, nr 3, s. 29 i n.

20 Ustawa konstytucyjna z dnia 17 października 1992 r. o wzajemnych stosunkach między władzą ustawodawczą i wykonawczą Rzeczypospolitej Polskiej oraz o samorządzie terytorialnym (Dz.U. z 1992 r. Nr 84, poz. 426 z późn. zm.). Dalej: MK.

21 Dla uniknięcia częstych powtórzeń określeniami „dekret” i „rozporządzenie z mocą ustawy” posługuję się zamiennie. Polski ustrojodawca sięgał po obie te nazwy, nie wykazując konsekwencji w wiązaniu każdej $z$ nich z określoną według klarownych kryteriów szczegółową konstrukcją normatywną (zob. M.J. Nowakowski, Ustawodawstwo delegowane w polskim prawie konstytucyjnym, „Przegląd Sejmowy” 2005, nr 3, s. 48).

22 Na temat wcześniejszych doświadczeń z dekretami zob. syntetyczne ujęcie: W. Skrzydło, Ustawodawstwo delegowane w polskim prawie konstytucyjnym, (w:) L. Garlicki, A. Szmyt (red.), Sześć lat Konstytucji Rzeczypospolitej Polskiej. Doświadczenia i inspiracje, Warszawa 2003, s. 271-275; M. J. Nowakowski, Ustawodawstwo..., op. cit., s. 49-56. Szerzej na temat regulacji normatywnej i praktyki w okresie międzywojennym zob. R. Kraczkowski, Dekretowanie ustaw w Polsce w latach 1918-1926, Warszawa 1994; idem, Rozporządzenia Prezydenta Rzeczypospolitej z mocą ustawy w latach 1926-1935, Warszawa 2007. 
Po pierwsze, w Polsce od czasów I Rzeczypospolitej co do zasady ${ }^{23}$ kultywuje się tradycję silnej izby poselskiej ${ }^{24}$, a wspomniane uprawnienia egzekutywy idą jej pod prąd. W tym świetle można stwierdzić, że aktualnie dostrzegalna racjonalizacja parlamentaryzmu już i tak sięgnęła daleko. Co prawda w literaturze zauważa się, że w ostatnim stuleciu istnienie ustawodawstwa delegowanego w Polsce nie stanowiło zjawiska nadzwyczajnego, a nawet wręcz przeciwnie - było „sytuacją normalną i powszechną" ${ }^{25}$. Ustawodawstwo to jednak w świetle konstytucji pozostawać miało wyjątkiem od zasady, a nie zasadą - choć zdarzały się okresy, w których praktyka znacząco odbiegała od założeń konstytucyjnych.

Po drugie, ambiwalentnie trzeba ocenić doświadczenia historyczne z dekretami. Warto wprawdzie odnotować sukces międzywojennych kodyfikacji wydawanych po wejściu w życie tzw. noweli sierpniowej z 2 sierpnia 1926 r. ${ }^{26}$ Nieraz kilkudziesięcioletni okres ich obowiązywania (czasami aż do przełomu XX i XXI wieku) dowiódł, że ich opracowanie poza parlamentem nie wpłynęło ujemnie na jakość tych aktów. Potwierdziły one swoją wartość - w tym elastyczność - w obrocie prawnym. $\mathrm{Z}$ drugiej strony dekrety kojarzą się zdecydowanie negatywnie $\mathrm{z}$ okresem komuni$\mathrm{zmu}^{27}$, na czele z tzw. Małym kodeksem karnym z 1946 r. ${ }^{28}$ i dekretami Rady Państwa z 1981 r. związanymi z wprowadzeniem stanu wojennego ${ }^{29}$.

Po trzecie, dekretowanie ustaw ogranicza zasadę podziału władzy, którą uważa się często za nierozerwalnie związaną z demokracją ${ }^{30}$. Analizując rozporządzenia z mocą ustawy znane MK Kazimierz Działocha akcentował wprawdzie, że nie oznaczały one odrzucenia podziału władzy, bo w oparciu o delegację ustawodawczą nie miało dochodzić do przeniesienia kompetencji ustawodawczych z parlamentu

Wyjątek stanowiły okresy obowiązywania: Konstytucji marcowej z 1921 r. po wejściu w życie noweli sierpniowej z 1926 r. i Konstytucji kwietniowej z 1935 r., która uprzywilejowała stanowisko ustrojowe Prezydenta RP (podporządkowano mu pozostałe organy władzy).

Zob. np. P. Sarnecki, uwaga nr 18 do art. 10, (w:) L. Garlicki (red.), Konstytucja Rzeczypospolitej Polskiej. Komentarz, t. V, Warszawa 2007, s. 22; L. Garlicki, Polskie prawo konstytucyjne. Zarys wykładu, wyd. 13, Warszawa 2009, s. 73. Autorzy ci piszą wręcz o przewadze Sejmu nad innymi organami władzy. M. J. Nowakowski, Ustawodawstwo..., op. cit., s. 47.

Mam na myśli m.in. rozporządzenia Prezydenta Rzeczypospolitej: z dnia 27 października 1933 r. - Kodeks zobowiązań (Dz.U. z 1933 r. Nr 82, poz. 598 z późn. zm.), z dnia 27 czerwca 1934 r. - Kodeks handlowy (Dz.U. z 1934 r. Nr 57, poz. 502 z późn. zm.), z dnia 24 października 1934 r. - Prawo upadłościowe (Dz.U. z 1934 r. Nr 93, poz. 834 z późn. zm.) i z dnia 24 października 1934 r. - Prawo o postępowaniu układowem (Dz.U. z 1934 r. Nr 93, poz. 836 z późn. zm.).

Właśnie tamte doświadczenia przesądziły o rezygnacji z istnienia dekretów w 1989 r., zob. D. Górecki, O przydatności instytucji dekretu z mocą ustawy w polskim prawie konstytucyjnym, (w:) A. Pułło (red.), Zagadnienia współczesnego prawa konstytucyjnego, Gdańsk 1993, s. 117.

28 Dekret z dnia 13 czerwca 1946 r. o przestępstwach szczególnie niebezpiecznych w okresie odbudowy państwa (Dz.U. z 1946 r. Nr 30, poz. 192 ze zm.).

29 Dekrety z dnia 12 grudnia 1981 r.: o stanie wojennym (Dz.U. z 1981 r. Nr 29, poz. 154), o postępowaniach szczególnych w sprawach o przestępstwa i wykroczenia w czasie obowiązywania stanu wojennego (Dz.U. z 1981 r. Nr 29, poz. 156), o przekazaniu do właściwości sądów wojskowych spraw o niektóre przestępstwa oraz o zmianie ustroju sądów wojskowych i wojskowych jednostek organizacyjnych Prokuratury Polskiej Rzeczypospolitej Ludowej w czasie obowiązywania stanu wojennego (Dz.U. z 1981 r. Nr 29, poz. 157).

30 Przed wejściem w życie MK, a po przełomie ustrojowym z 1989 r. zasadę podziału władzy - choć nie była wysłowiona w tekście gruntownie znowelizowanej konstytucji z 1952 r. - uznawano za wynikającą z zasady demokratycznego państwa prawnego, zob. H. Suchocka, Zasada podziału i zrównoważenia władz, (w:) W. Sokolewicz (red.), Zasady podstawowe polskiej Konstytucji, Warszawa 1998, s. 148. 
na rząd, a jedynie do upoważnienia gabinetu do wydawania aktów rangi ustawy, co badacz ten uznawał za konsekwencję zasady podziału władzy ${ }^{31}$. Należy zgodzić się z powoływanym autorem, że współcześnie nieaktualne jest rygorystyczne spojrzenie na podział władzy ${ }^{32}$. Nie zmienia to jednak faktu, że w ramach tego podziału to parlament sprawuje władzę ustawodawczą, a omawiane uprawnienie oznacza dopuszczenie organu władzy wykonawczej do wydawania aktów normatywnych tej samej rangi co ustawa. Zachodzi istotny wyjątek od zasady, więc uzasadniona wydaje się teza o ograniczeniu tej zasady (tyle że dopuszczonym konstytucyjnie) ${ }^{33}$.

Po czwarte, inne niż ustawy akty jej rangi szczególnie silne uzasadnienie posiadają w systemie sesyjnym prac parlamentu, a MK wprowadziła zasadę permanencji, którą następnie utrzymała Konstytucja RP z 1997 r. Brak sesji, a co za tym idzie przerw pomiędzy nimi, sprawia, że to akurat uzasadnienie dla dekretów nie miałoby już zastosowania ${ }^{34}$.

Po piąte, jeśli nie wykluczy się upoważniania w rozporządzeniach $\mathrm{z}$ mocą ustawy Rady Ministrów lub jej członków do wydawania rozporządzeń wykonawczych, powstaje ryzyko, że podejmowane byłyby próby szerokiego sięgania przez rząd po regulację dekretami i wydawanymi na ich podstawie rozporządzeniami wykonawczymi, co wiązałoby się z umniejszaniem kompetencji prawodawczej parlamentu ${ }^{35}$. Upoważnienia do wydania rozporządzeń wykonawczych, jakie konstruowałaby dla samej siebie lub swoich członków Rada Ministrów, mogłyby w praktyce częściej odbiegać od restrykcyjnych standardów konstytucyjnych niż te, które formułuje parlament w ustawach.

Artykuł 23 MK z 1992 r. stanowi dobry punkt odniesienia dla rozważań nad rozporządzeniem z mocą ustawy nie tylko dlatego, że wspomniana ustawa zasadnicza była ostatnią w Polsce, przewidującą istnienie tego rodzaju źródła prawa. Drugi powód wiąże się z użytym w poprzednim zdaniu słowem ,,przewidująca” - w praktyce na prawie wydawania rozporządzeń z mocą ustawy przez Radę Ministrów się skończyło, nie wydano bowiem ani jednego takiego aktu ${ }^{36}$. Dlaczego tak się stało, skoro

31 Zob. K. Działocha, Rozporządzenia z mocą ustawy w świetle ustawy konstytucyjnej z dnia 17 października 1992 r., „Przegląd Sejmowy” 1993, nr 1, s. 58.

32 Ibidem.

33 Przeciwny niż K. Działocha pogląd wyraził P. Sarnecki. Jego zdaniem art. 23 MK jest „sprzeczny z ideą podziału władzy i ogranicza prawa parlamentu" (P. Sarnecki, Rozporządzenie z mocą ustawy w ustawie konstytucyjnej z 17 X 1992, „Państwo i Prawo” 1993, z. 3, s. 5). Inny autor określił dekrety mianem „korekty podziału władzy” (D. Górecki, O przydatności..., op. cit., s. 116).

34 Pod rządami MK podkreślał to np. P. Sarnecki, Rozporządzenie..., op. cit., s. 4.

35 W nawiązaniu do przepisów MK niebezpieczeństwo takie sygnalizowali K. Wojtyczek i B. Naleziński (Rozporządzenie z mocą ustawy w polskim systemie kontroli konstytucyjności prawa, „Przegląd Sejmowy” 1995, nr 3, s. 38). Dostrzegali oni jednak zarówno argumenty na rzecz, jak i przeciwko dopuszczalności zawierania w rozporządzeniach z mocą ustawy upoważnień do wydawania rozporządzeń wykonawczych, nie zajmując ostatecznie jednoznacznego stanowiska (zob. ibidem, s. 38-39). Podobnych wątpliwości nie miał K. Działocha, stwierdzając, że „rozporządzenie z mocą ustawy na równi z ustawą jest bazą prawną ich [tj. organów wykonawczych - dop. autora] aktów normatywnych" (K. Działocha, Rozporządzenia..., op. cit., s. 54).

36 Jeden raz Rada Ministrów wystąpiła z projektem ustawy upoważniającej (druk nr 728 z 25 stycznia 1993 r., Sejm I kadencji), ale nie doszło do głosowania w tej sprawie przez Sejm, więc rozporządzenia z mocą ustawy nie mogły być przez rząd wydawane. 
zauważono, że powrót do dekretów po okresie rezygnacji z nich zapoczątkowanym ustawą z dnia 7 kwietnia 1989 r. o zmianie Konstytucji PRL ${ }^{37}$, wynikał z przekonania o ich przydatności w procesie głębokich reform (w tym gospodarczych) rozpoczętych w Polsce po przełomie ustrojowym ${ }^{38}$ ?

W literaturze wskazywano na mankamenty ówcześnie przyjętej konstrukcji rozporządzeń z mocą ustawy. Dostrzegano luki w konstytucyjnej regulacji, które częściowo dawały się łatwo wypełnić w drodze odpowiedniej wykładni (np. art. 23 nie stanowił nic o udziale Senatu w procedurze uchwalania ustawy upoważniającej Radę Ministrów do wydawania rozporządzeń z mocą ustawy, jednak uznawano, że samo pojęcie ustawy oznacza wymóg włączenia Senatu ${ }^{39}$ ), a częściowo rodziły znacznie poważniejsze problemy interpretacyjne. W tym drugim przypadku chodziło szczególnie o wykładnię tzw. klauzul negatywnych, czyli materii, które wyłączono spod możliwości normowania przez rząd za pomocą dekretów ${ }^{40}$. Jako problematyczna jawiła się zwłaszcza kategoria „wolności i praw osobistych obywateli, ich wolności i praw politycznych oraz praw i obowiązków wynikających ze stosunku pracy i ubezpieczeń społecznych" "¹. Jednakże za zasadniczą wadę rozporządzeń z mocą ustawy przedstawiciele doktryny powszechnie uważali brak następczej kontroli wydanych już rozporządzeń, dokonywanej przez parlament w drodze ich zatwierdzania ${ }^{42}$. Brak tej instytucji nie pozbawiał wprawdzie całkowicie parlamentu możliwości kontroli rządu w zakresie wydawanych dekretów, ale - jak podkreślał Feliks Siemieński w grę wchodziła jedynie „kontrola bardzo ograniczona” (m.in. w drodze interpelacji i zapytań poselskich, odmowy absolutorium czy wotum nieufności $)^{43}$.

Za jeden z najistotniejszych mankamentów ówczesnej konstrukcji uważam ust. 4 art. $23 \mathrm{MK}$, operujący przytoczonym już niejasnym sformułowaniem o zakazie regulowania określonych materii z zakresu praw i wolności jednostki. Nie sam fakt wprowadzenia tego ograniczenia - niewątpliwie słusznego - budził zastrzeżenia, a jedynie brzmienie przepisu, mogące zniechęcać Radę Ministrów do projektowa-

37 Dz.U. z 1987 r. Nr 19, poz. 101.

38 Zob. np. K. Działocha, Rozporządzenia..., op. cit., s. 49 (przyp. 4), W. Skrzydło, Ustawodawstwo..., op. cit., s. 275 .

39 Tak np. K. Działocha, Rozporządzenia..., op. cit., s. 59; P. Sarnecki, Rozporządzenie..., op. cit., s. 6; L. Garlicki, uwaga nr 16 do art. 23, (w:) L. Garlicki (red.), Komentarz do Konstytucji Rzeczypospolitej Polskiej, t. I, Warszawa 1995, s. 10.

40 Zakres materii wyłączonych spod regulacji rozporządzeniami z mocą ustawy był najszerszy spośród dotychczasowych unormowań konstytucyjnych tej kwestii (P. Sarnecki, Rozporządzenie..., op. cit., s. 6).

41 Rozbieżną interpretację przedstawili L. Garlicki (uwaga nr 22 do art. 23..., op. cit., s. 13) i P. Sarnecki (Rozporządzenie..., op. cit., s. 7). Na poważne wątpliwości na tym tle wskazywał też np. K. Działocha, Rozporządzenia..., op. cit., s. 61-62.

42 Zob. np. D. Górecki, O przydatności..., op. cit., s. 120; P. Sarnecki, Rozporządzenie..., op. cit., s. 8-9; A. Gwiżdż, Ustawodawstwo i kompetencje prawotwórcze rządu (w świetle ustawy konstytucyjnej z 17 października 1992 roku), (w:) M. Kruk (red.), „Mała konstytucja” w procesie przemian ustrojowych w Polsce, Warszawa 1993, s. 123-124; S. Patyra, Mechanizmy..., op. cit., s. 97 i 278.

43 F. Siemieński, Kontrola Sejmu nad rozporządzeniami z mocą ustawy, (w:) M. Kruk (red.), „Mała konstytucja”..., op. cit., s. 139-140. Za niewystarczające uważał te środki także A. Gwiżdż, wyrażając obawę, że brak wymogu zatwierdzania przez Sejm rozporządzeń z mocą ustawy będzie prowadził do niechętnego uchwalania ustaw upoważniających do ich wydawania (zob. A. Gwiżdż, Ustawodawstwo..., op. cit., s. 124). 
nia ustaw upoważniających. Potencjalny rozporządzeniodawca mógł się obawiać, czy planowana regulacja pośrednio nie wkroczy w materię wyłączności ustawowej, a tym samym czy nie wzbudzi wątpliwości konstytucyjnych.

Do przytoczonej listy zarzutów przedstawicieli doktryny można dodać i kolejne. $\mathrm{Z}$ punktu widzenia racjonalizacji parlamentaryzmu niewłaściwe było ustanowienie wymogu bezwzględnej większości głosów dla uchwalenia ustawy upoważniającej (art. 23 ust. $1 \mathrm{MK}$ ). To bowiem czyniło omawianą instytucję co do zasady nieprzydatną gabinetom mniejszościowym, utrudniając im prowadzenie polityki państwa. Za jeszcze poważniejsze przeciwwskazanie dla stosowania art. 23 uważam jednak nadmiernie rozbudowaną rolę Prezydenta w procesie kontroli dekretów. Prawo wystąpienia z wnioskiem do Trybunału Konstytucyjnego nie podlega zakwestionowaniu, a z racji wyjątkowego charakteru dekretów możliwość kontroli prewencyjnej była tu nawet wysoce pożądana. Na cóż jednak wysiłek rządu, polegający na wniesieniu do Sejmu projektu ustawy upoważniającej, na uzyskaniu bezwzględnej większości i na wydaniu rozporządzenia, skoro głowa państwa mogła je zawetować (art. 23 ust. 7 zd. 1)? Miało to zresztą następować łatwiej niż w przypadku ustaw, skoro odmowa podpisania nie wymagała umotywowania, a weta nie dało się ,przełamać”. Na podstawie art. 23 ust. 7 zd. 2 Rada Ministrów mogła jedynie wystąpić do Sejmu $\mathrm{z}$ rozporządzeniem przekształconym w projekt ustawy ${ }^{44}$. Bez sojuszu z Prezydentem rządowe dekrety były z góry skazane na porażkę.

W doktrynie dostrzeżono, że jednym z uzasadnień dla istnienia rozporządzeń z mocą ustawy bywa zamiar reagowania na stan „nagłej konieczności państwowej”, czemu rozwiązanie zawarte w art. 23 MK nie odpowiadało, bo ów stan mógł wymagać pełnomocnictw do wydania rozporządzenia, których w momencie uchwalania ustawy upoważniającej parlament nie był w stanie przewidziećc ${ }^{45}$. W nawiązaniu do tej myśli wolno dodać, że sama konieczność uchwalenia uprzednio przez parlament ustawy upoważniającej mogła zniweczyć ten zamiar, gdyby postępowanie legislacyjne w tym zakresie się przedłużało. Dlatego, choć nie bez wahań, opowiadałbym się za tym, abyśmy w razie ewentualnego przywrócenia dekretów do polskiego systemu źródeł prawa przemyśleli sięgnięcie nie po ich postać znaną z MK (dekrety z upoważnienia ustawy), lecz po dekrety z upoważnienia konstytucji ${ }^{46}$. Wówczas rząd nie musiałby uzyskać pełnomocnictwa od parlamentu dla uchwalania prawa o mocy ustawy i realizacja podstawowych celów dekretów zostałaby zagwarantowana w pełni, a nie byłaby uzależniona od dobrej woli ustawodawcy. Oczywistą wadę takiego rozwiązania stanowi poważne ograniczenie wynikającej z zasady

\footnotetext{
44 Niezbyt przekonuje pogląd, jakoby to ostatnie uprawnienie świadczyło o przewadze Rady Ministrów nad Prezydentem (tak F. Siemieński, Kontrola..., op. cit., s. 140). Rząd nie miałby przecież żadnej gwarancji, że parlament taki projekt przekształci w ustawę.

45 Tak P. Sarnecki, Rozporządzenie..., op. cit., s. 4.

46 Na temat tego rozróżnienia zob. K. Działocha, Rozporządzenia..., op. cit., s. 56.
} 
podziału władzy zasady wyłączności kompetencji ustawodawczej parlamentu ${ }^{47}$. W literaturze dekrety (w każdej postaci) łączone bywają - również przez autorów nieodżegnujących się od tej instytucji lub nawet warunkowo opowiadających się za jej istnieniem - z obawami o ewolucję systemu rządów w kierunku autorytarnym ${ }^{48}$; nazywa się ją też przejawem „skrajnej racjonalizacji mechanizmów rządzenia"49". Pomimo to wydaje się, że wprowadzenie odpowiednich zabezpieczeń ustrojowych - niekoniecznie takich, jak zwykle postulowane w doktrynie - neutralizowałoby wspomniane zagrożenie. Najpierw trzeba jednak rozstrzygnąć dylemat preferencji wartości. Albo dokonujemy fetyszyzacji podziału władzy i pozycji ustrojowej parlamentu, albo wybieramy większą sprawność i efektywność systemu rządów, czyli opowiadamy się za dalszą racjonalizacją polskiego parlamentaryzmu. Określenie „fetyszyzacja” znajduje tutaj uzasadnienie, skoro realna rola parlamentu, przynajmniej w zakresie rozstrzygnięć kierunkowych, jest współcześnie silnie uwarunkowana kształtem systemu partyjnego. Czy Kazimierz Marcinkiewicz musiał złożyć dymisję rządu dlatego, że utracił zaufanie Sejmu, czy dlatego, że utracił zaufanie prezesa swojej partii politycznej? To tylko jeden z wielu przykładów.

Bez wątpienia decyzja o wyborze rozporządzeń z mocą ustawy z upoważnienia konstytucji powinna się wiązać z zapewnieniem odpowiedniej kontroli nad ich wydawaniem. Inaczej jednak niż powoływanym wcześniej badaczom nie wydaje mi się celowe domaganie się bezpośredniej kontroli politycznej nad dekretami realizowanej przez parlament poprzez ich zatwierdzanie. Jak stwierdził Piotr Winczorek, „po to są dekrety, żeby Sejm się nie wypowiadał" ${ }^{50}$. Przy istnieniu rządu większościowego owa kontrola polityczna mogłaby stanowić czystą formalność, zaś w przypadku gabinetu mniejszościowego zachodziłoby niebezpieczeństwo, że parlament odmawiałby zatwierdzenia wszelkich rozporządzeń z mocą ustawy, co pozbawiałoby ich wydawanie sensu. Ewentualnie warto by się zastanowić nad wymogiem zatwierdzania rządowych rozporządzeń z mocą ustawy przez parlament kolejnej kadencji, gdyż nawet w razie jego znacząco odmiennego od poprzednika składu politycznego upływ czasu mógłby skłaniać posłów do akceptacji już wydanych rozporządzeń.

W razie ponownego sięgnięcia po dekrety należałoby starannie przemyśleć katalog materii wyłączonych spod możliwości normowania za ich pomocą ${ }^{51}$ i okre-

Jakkolwiek S. Patyra dostrzega zalety rozporządzeń z upoważnienia konstytucji związane z efektywnością takiego środka prawnego, to jednak m.in. ze względu na niedostateczny demokratyzm tworzenia prawa w tej formule i większą popularność w innych państwach dekretów z upoważnienia ustaw ostatecznie preferuje restytucję właśnie tego drugiego rodzaju dekretów, zob. S. Patyra, Mechanizmy..., op. cit., s. 282-283.

D. Górecki, O przydatności..., op. cit., s. 116.

S. Patyra, Mechanizmy..., op. cit., s. 274.

Cyt. za: A. Szmyt, W sprawie rozporządzeń z mocą ustawy, „Przegląd Sejmowy” 1993, nr 2, s. 124.

Dotyczyć to powinno zarówno dekretów $z$ upoważnienia konstytucji, jak i z upoważnienia ustawy, ale w tym pierwszym przypadku katalog powinien być szerszy, z racji wyeliminowania instytucji parlamentarnych pełnomocnictw dla rządu do wydawania tych dekretów. Trafny wydaje się pogląd, że za wzór mógłby tutaj posłużyć np. art. 123 ust. 1 Konstytucji RP (tak S. Patyra, Mechanizmy..., op. cit., s. 283-284). Podobnie jak M.J. Nowakowski (Ustawodawstwo..., op. cit., s. 62) nie wykluczyłbym też obrania za punkt wyjścia art. 23 ust. 4 MK [powoływany badacz omyłkowo wskazał na ust. 3, jednak niewątpliwie miał na myśli ust. 4 - dop. autora], tyle że zdecydowanego 
ślenie maksymalnego okresu, np. 6-miesięcznego, w którym w toku danej kadencji parlamentu rząd miałby prawo z nich korzystać (tak, aby w praktyce nie stały się one zasadą, a ustawy - wyjątkiem ${ }^{52}$ ). Rozważyć wypadałoby też środki kontroli prawnej, w tym ustanowienie prawa prewencyjnej kontroli dekretów przez Trybunał Konstytucyjny na wniosek grupy posłów lub senatorów, marszałków izb parlamentu lub Rzecznika Praw Obywatelskich, a być może nawet wprowadzenie obowiązku prewencyjnej kontroli ich konstytucyjności, choć w obu wariantach przy względnie krótkim terminie dla TK na rozpoznanie wniosku ${ }^{53}$. Prawo uruchomienia kontroli prewencyjnej powinien także posiadać - tak jak na gruncie MK - Prezydent, ale pozbawić należałoby go weta do rządowych rozporządzeń z mocą ustawy, gdyż w przeciwnym wypadku w razie konfliktu politycznego pomiędzy nim a rządem dekrety w znacznej mierze utraciłyby walor skuteczności i znów pozostawałyby „martwą literą prawa". Z uwagi też na powierzenie przez Konstytucję RP prowadzenia polityki państwa Radzie Ministrów, a nie Prezydentowi, to właśnie temu pierwszemu, a nie drugiemu organowi przysługiwać powinno prawo wydawania omawianych aktów normatywnych ${ }^{54}$.

Mimo zastrzeżeń wydaje się, że wiele przemawia za przemyśleniem powrotu do koncepcji dekretów wydawanych przez Radę Ministrów. Mogłoby się to okazać przydatne w szczególności rządom mniejszościowym. W przeciwnym bowiem razie dochodzi, czy też może dojść, do dysfunkcjonalności działalności gabinetu, a w efekcie nie jest wypełniana - lub jest realizowana ułomnie - wyrażona we Wstępie do Konstytucji RP idea rzetelności i sprawności działania instytucji publicznych. Rząd mniejszościowy staje się zakładnikiem niechętnej mu, a co najwyżej tolerującej go w obawie przed kryzysem rządowym i skróceniem kadencji Sejmu, negatywnej większości parlamentarnej, nieraz współtworzonej przez konglomerat sprzecznych programowo ugrupowań. Także jednak w przypadku gabinetu większościowego powrót do dekretów mógłby przynieść korzyści. Uniemożliwione zostałyby bowiem parlamentowi ingerencje merytoryczne w regulacje wymagające wiedzy i przygotowania specjalistycznego, które aktualnie niekiedy prowadzą - w drodze poprawek - do psucia prawa ${ }^{55}$. Rząd może przygotować nawet najlepszy projekt ustawy, ale wskutek szkodliwych interwencji parlamentarzystów jego jakość ulega obniżeniu. Alternatywą byłoby dopuszczenie jedynie pełnej akceptacji lub odrzucenia projektu przez Sejm.

uściślenia wymagałaby kategoria praw i wolności jednostki, w które nie wolno ingerować dekretami, tak aby uniknąć wątpliwości wyłaniających się na tle ówczesnego stanu prawnego.

52 Jak zdarzało się w PRL, co słusznie napiętnowano (zob. D. Górecki, O przydatności..., op. cit., s. 118).

53 Brak terminu lub długi termin mogłyby pozbawić dekrety podstawowego atutu, czyli skuteczności.

54 Tak też M.J. Nowakowski, Ustawodawstwo..., op. cit., s. 62; S. Patyra, Mechanizmy..., op. cit., s. 279.

55 Por. np. M.J. Nowakowski, Ustawodawstwo..., op. cit., s. 60. 
Choć współcześnie, po reformach wprowadzonych w Unii Europejskiej Traktatem z Lizbony, dąży się do wzmacniania roli parlamentów narodowych ${ }^{56}$, opowiadałbym się za kierunkiem odwrotnym, tj. za wzmacnianiem pozycji rządu. Stwarzałoby to korzystniejsze warunki dla sprawnej realizacji kluczowych zadań przez państwo. Zaś w sferze prawotwórstwa mogłoby to przynieść poprawę w zakresie terminowej i należytej implementacji dyrektyw unijnych. Służyłyby temu właśnie rozporządzenia Rady Ministrów z mocą ustawy. Aktualnie implementacja wiąże się z koniecznością uchwalania ustaw, co nie sprzyja dochowywaniu wymaganego przez traktaty unijne tempa pracy, a jednocześnie parlamentarzyści posiadają przestrzeń dla uchwalania do rządowych projektów poprawek, które niejednokrotnie prowadzą do wadliwej implementacji ${ }^{57}$.

Alternatywą dla rządowych dekretów mogłoby okazać się przyjęcie konstrukcji podobnej do niemieckiego stanu (wyższej) konieczności ustawodawczej. Artykuł 81 Ustawy Zasadniczej RFN z dnia 23 maja 1949 r. $^{58}$ przewiduje - na wypadek, gdy Bundestag odmówi kanclerzowi wotum zaufania i pod warunkiem aprobaty ze strony Prezydenta RFN i Bundesratu - możliwość uzyskiwania mocy obowiązującej przez rządowe projekty ustaw, które Bundestag odrzucił, choć kanclerz powiązał je z wnioskiem o wotum zaufania lub rząd nadał im klauzulę pilności. Ów stan konieczności ustawodawczej wolno ogłaszać ponownie dla kolejnych projektów przez 6 miesięcy podczas danej kadencji kanclerskiej. Ustawy „uchwalone” w ten sposób nie mogą zmieniać postanowień UZ ani też zawieszać stosowania jej przepisów. Artykuł $81 \mathrm{UZ}$ nie jest pozbawiony wad, ale zasadniczą jego zaletę stanowi zapewnienie instrumentarium działania rządowi mniejszościowemu. Jednak ewentualne sięgnięcie po niemiecki wzorzec w Polsce wymagałoby nie dosłownej, a zmodyfikowanej recepcji ${ }^{59}$.

W ramach podsumowania wolno stwierdzić, że nie wymaga zmian realizowana przez obecną Konstytucję RP koncepcja rozporządzeń wykonawczych, zaś de lege ferenda należy postulować dopracowanie szczegółów normatywnych konstrukcji rozporządzeń z mocą ustawy wydawanych przez Prezydenta na podstawie art. 234 ust. 1. Zasadniczo wydaje się jednak, że kompetencje głowy państwa w dziedzinie prawotwórstwa ukształtowano - na tle jej ogólnej pozycji ustrojowej - prawidłowo. Natomiast głównym problemem pozostaje zbyt wąski zakres uprawnień Rady Ministrów do stanowienia prawa powszechnie obowiązującego. Na rozważenie zasługuje

Szerzej zob. np. K. Wojtyczek, Wpływ Traktatu z Lizbony na ustrój Polski, „Przegląd Sejmowy” 2010, nr 4, s. 35-36.

Tak też np. M.J. Nowakowski, Ustawodawstwo..., op. cit., s. 60. Zauważono, że postulat wykorzystania rozporządzeń z mocą ustawy jako środka implementacji prawa UE budzi stosunkowo najmniej kontrowersji (zob. S. Patyra, Mechanizmy..., op. cit., s. 278 i cyt. tam literaturę).

BGBI. 1949, s. 1 z późn. zm. Dalej w skrócie: „UZ”.

Szerzej o art. 81 UZ i możliwościach jego recepcji zob. M. Pach, Stan konieczności ustawodawczej - niemiecka osobliwość czy potencjalne źródło inspiracji recepcyjnej?, „Przegląd Sejmowy” 2013, nr 6, s. 75 i n. 
restytucja wydawanych przez rząd rozporządzeń z mocą ustawy ${ }^{60}$ lub ustanowienie alternatywy dla nich. Zarazem racjonalizacja parlamentaryzmu we wskazanym kierunku wydaje się ideą słuszną, ale niełatwą w realizacji. Niezbędne byłoby staranne przemyślenie kształtu konkretnych propozycji. Nie ma przecież sensu uchwalenie zmian w Konstytucji, które ze względu na swój dysfunkcjonalny charakter okazałyby się mało przydatne w praktyce ustrojowej, tak jak nieprzydatny okazał się art. $23 \mathrm{MK}$.

\section{BIBLIOGRAFIA}

Balicki Ryszard. 2010. Relacje między organami władzy wykonawczej - na drodze do systemu kanclerskiego? W Konieczne i pożądane zmiany w Konstytucji RP z 2 kwietnia 1997 roku, 329-353. Wrocław: Wydawnictwo Uniwersytetu Wrocławskiego.

Banaszak Bogusław. 2006. „Egzekutywa w Polsce - stan obecny i uwagi de lege fundamentali ferenda”. Przegląd Sejmowy (3): 9-27.

Borkowski Tomasz. 1997. „System rządów w nowej Konstytucji”. Państwo i Prawo (11-12): 71-85.

Brodziński Witold. 1997. System parlamentarno-gabinetowy - wykorzystanie modelu rządów parlamentarno-gabinetowych w konstytucji Rzeczypospolitej Polskiej. W Konstytucyjne systemy rządów. Możliwości adaptacji do warunków polskich, 35-55. Warszawa: Wydawnictwo Sejmowe.

Działocha Kazimierz. 1993. „Rozporządzenia z mocą ustawy w świetle ustawy konstytucyjnej z dnia 17 października 1992 r.”. Przegląd Sejmowy (1): 49-67.

Działocha Kazimierz. 2001. Uwagi do art. 92. W Konstytucja Rzeczypospolitej Polskiej. Komentarz, t. II, 1-35. Warszawa: Wydawnictwo Sejmowe.

Garlicki Leszek. 2009. Polskie prawo konstytucyjne. Zarys wykładu. Warszawa: LIBER.

Garlicki Leszek. 1995. Uwagi do art. 23. W Komentarz do Konstytucji Rzeczypospolitej Polskiej, t. I, 1-22. Warszawa: Wydawnictwo Sejmowe.

Górecki Dariusz. 1993. O przydatności instytucji dekretu z mocą ustawy w polskim prawie konstytucyjnym. W Zagadnienia współczesnego prawa konstytucyjnego, 116-120. Gdańsk: Wydawnictwo Uniwersytetu Gdańskiego.

Gwiżdż Andrzej. 1993. Ustawodawstwo i kompetencje prawotwórcze rządu (w świetle ustawy konstytucyjnej z 17 października 1992 roku). W „Mała konstytucja” w procesie przemian ustrojowych w Polsce, 107-135. Warszawa: Wydawnictwo Sejmowe.

Kraczkowski Romuald. 1994. Dekretowanie ustaw w Polsce w latach 1918-1926. Warszawa: Wydawnictwo Sejmowe.

Kraczkowski Romuald. 2007. Rozporządzenia Prezydenta Rzeczypospolitej z mocą ustawy w latach 1926-1935. Warszawa: Wydawnictwo Sejmowe.

60 Opowiedzieli się za tym również powoływani powyżej M. J. Nowakowski i S. Patyra, ale w szczegółach ich stanowisko odbiega od prezentowanego $w$ tym miejscu. 
Kruk Maria. 2006. Idea stabilności i efektywności rządów w Konstytucji RP z 1997 r. W Prawo w XXI wieku. Księga pamiątkowa 50-lecia Instytutu Nauk Prawnych Polskiej Akademii Nauk, 407426. Warszawa: Wydawnictwo Naukowe Scholar.

Kruk Maria. 1998. System rządów w Konstytucji Rzeczypospolitej Polskiej z 2 kwietnia 1997 roku. W Ustrój polityczny Rzeczypospolitej Polskiej w nowej Konstytucji z 2 kwietnia 1997 roku, 17-52. Lublin: Wydawnictwo Uniwersytetu Marii Curie-Skłodowskiej.

Łabno Anna. 2005. „Parlamentaryzm zracjonalizowany. Przyczynek do dyskusji”. Przegląd Prawa i Administracji (LXV): 7-21.

Nowakowski Maciej J. 2005. „Ustawodawstwo delegowane w polskim prawie konstytucyjnym”. Przegląd Sejmowy (3): 47-64.

Pach Maciej. 2013. „Stan konieczności ustawodawczej - niemiecka osobliwość czy potencjalne źródło inspiracji recepcyjnej?”. Przegląd Sejmowy (6): 75-92.

Patyra Sławomir. 2012. Mechanizmy racjonalizacji procesu ustawodawczego w Polsce w zakresie rządowych projektów ustaw. Toruń: Wydawnictwo Adam Marszałek.

Prokop Krzysztof. 2002. „O dopuszczalności oraz zakresie przedmiotowym rozporządzeń z mocą ustawy w czasie stanu wojennego". Przegląd Sejmowy (3): 47-59.

Sarnecki Paweł. 1993. „Rozporządzenie z mocą ustawy w ustawie konstytucyjnej z 17 X 1992”. Państwo i Prawo (3): 3-10.

Sarnecki Paweł. 2007. Uwagi do art. 10. W Konstytucja Rzeczypospolitej Polskiej. Komentarz, t. V, 1-23. Warszawa: Wydawnictwo Sejmowe.

Siemieński Feliks. 1993. Kontrola Sejmu nad rozporządzeniami z mocą ustawy. W „Mała konstytucja” w procesie przemian ustrojowych w Polsce, 136-142. Warszawa: Wydawnictwo Sejmowe.

Skrzydło Wiesław. 2003. Ustawodawstwo delegowane w polskim prawie konstytucyjnym. W Sześć lat Konstytucji Rzeczypospolitej Polskiej. Doświadczenia i inspiracje, 270-278. Warszawa: Wydawnictwo Sejmowe.

Suchocka Hanna. 1998. Zasada podziału i zrównoważenia władz. W Zasady podstawowe polskiej Konstytucji, 146-164. Warszawa: Wydawnictwo Sejmowe.

Szmyt Andrzej. 1993. „W sprawie rozporządzeń z mocą ustawy”. Przegląd Sejmowy (2): 123-128.

Szymanek Jarosław. 2007. „Racjonalizacja parlamentarnego systemu rządów”. Przegląd Sejmowy (1): $35-64$.

Wojtyczek Krzysztof. 2010. „Wpływ Traktatu z Lizbony na ustrój Polski”. Przegląd Sejmowy (4): 23-40.

Wojtyczek Krzysztof, Bogumił Naleziński. 1995. „Rozporządzenie z mocą ustawy w polskim systemie kontroli konstytucyjności prawa". Przegląd Sejmowy (3): 35-47.

Wronkowska Sławomira. 2005. Model rozporządzenia jako aktu wykonawczego do ustaw w świetle Konstytucji i praktyki. W Konstytucyjny system źródeł prawa w praktyce, 71-94. Warszawa: Wydawnictwo Sejmowe.

Żabicka-Kłopotek Monika. 2006. „Wytyczne” jako element upoważnienia do wydania rozporządzenia (na tle artykułu 92 Konstytucji RP)". Przegląd Sejmowy (3): 29-45. 
THE COMPETENCES OF EXECUTIVE POWER TO ENACT LEGAL ACTS IN THE SCOPE OF UNIVERSALLY BINDING LAW IN THE 1997 CONSTITUTION OF THE REPUBLIC OF POLAND - THE PRESENT SITUATION AND DE LEGE FERENDA POSTULATES

Abstract: The article discusses the issue of the scope of the competences of executive power to enact universally binding legal acts in the light of the Polish 1997 Constitution. According to the author, the powers of the president in this field generally are delimited properly. However it seems to be necessary to clarify some details of the institution of extraordinary regulations having the force of statute, enacted during a state of martial law. On the other hand, the constitutional position of the Council of Ministers in the discussed area should be strengthened, as it is the government who conducts external as well as internal policy of Poland. In order to enable each Council of Ministers (including minority cabinets) the effective fulfilment of this function, the restitution of the governmental regulations having the force of statute, present in the 1992 so-called Small Constitution, should be considered. At the same time some significant modifications have to be provided to this legal construct. Otherwise it would remain only a letter of the constitution, as it happened on the ground of the Small Constitution.

Keywords: competences to enact legal acts, sources of law, executive power, regulations having the force of statute, regulations, rationalisation of parliamentary system

Słowa kluczowe: kompetencje prawotwórcze, źródła prawa, władza wykonawcza, rozporządzenia $\mathrm{z}$ mocą ustawy, rozporządzenia, racjonalizacja systemu parlamentarnego 